\title{
Investment in children as a public good: the example of the Family 500+ Programme
}

Marek Rymsza

\section{Introduction: what is the Family 500+ Programme?}

The Family 500+ Programme (Program Rodzina 500+, hereinafter PR500+) is a governmental scheme that lies at the intersection of social and family policies, implemented in Poland since April 2016 under provisions of the Act on State Support in Raising Children (2016). The benefit has a fixed value of PLN 500 per month per child (about 120 Euro) ${ }^{1}$. At the same time, the first (oldest) child in the family is entitled to this benefit only after meeting the income criterion ${ }^{2}$, while the second and the subsequent children are eligible regardless of the size of the family's income. Social services have the right to control how the funds obtained from the programme are spent by parents and - in cases where evident wastage of funds is found - to exchange cash benefits for material assistance ${ }^{3}$. The benefits are paid to 2.62 million Polish families raising almost 4 million children. Expenditure from the state budget for the implementation of the programme is on average about PLN 2 billion per month. In the period of April 2016 - July 2017, the cost of payment of the benefit amounted to PLN 30.8 billion (MRPiPS 2017).

The announcement of launching the programme was presented in 2014 in a manifesto of the conservative political party Law and Justice (Zdrowie, Praca, Rodzina 2014: 108), which won the parliamentary elections in Poland in autumn 2015, and created an independent majority government. No green paper

1 The amount is raised to PLN 1200 if the child has legal disability status issued by a Disability Assessment Board.

2 The benefit is due if the net income per person in the family does not exceed PLN 800 .

3 In practice, the services make use of this right sporadically. 
was presented prior the adoption of the said Act at the beginning of 2016. The objectives of the programme were indicated in the justification attached to the draft law submitted to the Seym as a government legislative initiative (Seym Paper No. 216/2016, justification). The objectives include: (1) reducing poverty of families, families with many children in particular; (2) long-term investment in children as a form of investment in human capital; (3) raising the fertility level of families to reverse, or at least stop the unfavourable demographic process of the ageing population.

The three basic objectives of the programme are interrelated, but the time perspective of each of them is different. Thus, the reduction of poverty, absolute poverty in particular, can be achieved in the short-term perspective. Just 1-2 years after implementation of the programme it is possible to conduct a preliminary estimate of its effectiveness in terms of achieving this aim (Szarfenberg 2017). The assessment of the implementation of the second objective, which is an investment in human capital, can be carried out in the medium term. In order to estimate the social rate of return of investments made by the programme, one must wait until the first children raised and educated using the 500+ benefit will reach adulthood. Reliable estimates in this respect can be carried out within 5-10 years after the implementation of the programme. Achieving the third goal, i.e. stopping the ageing process by increasing the fertility rate of women in the procreative age is an effect planned in the long-term perspective, which covers a dozen or more years. Changes in the number of children born measured in a shorter time perspective (e.g. year to year) do not allow to judge the durability of the demographic trend (Kotowska 2017b).

After eighteen months that passed since the implementation of the programme, it is impossible to perform a comprehensive assessment of its effectiveness and efficiency. On the other hand, an in-depth analysis of the structure and premises of the programme reveal the innovation in public planning in the social area in comparison to the approach dominant in Polish social policy during the time of transformation (1989-2004) and in the following decade (2005-2015). This study indicates that the innovation of PR500+ lies in treating public support for families bringing up children as an investment in human capital and children as a public good. This investment profile of the programme must be somehow revealed since the PR500+ is hybrid in nature, and investment orientation is an element of a broader change in the state's development paradigm, and at the same time, a manifestation of a shift in the organisation of public social support: from a preference for a selective approach towards a more universal approach. The four aspects of the programme are: 1) investment, (2) hybridity, (3) universality, and (4) a new development paradigm that are functionally interrelated and mutually dependent. That is why it is worth presenting them together. This approach is adopted in this study ${ }^{4}$.

4 In this paper I use comments about PR500+, which I presented in a non-scientific essay Rymsza 2017. 


\section{The family 500+ Programme as a hybrid}

The PR500+ is hybrid in nature due to the following three aspects of its structure: (1) combining different rules governing the availability of benefits; (2) combining social and investment functions; (3) linking social intervention (reduction of poverty) with impact on demographic processes (increase in fertility). The section below contains brief descriptions of these aspects.

The combination of: (i) the logic of the universal access to the benefit, according to which every second and subsequent child is eligible, and (ii) the logic of selective and income related, benefit, when applied to the first child, did not result from the premises of the programme. The introduction of the income criterion in the case of the first child in the family was related to the necessity of adjusting expenses to the funds available in the state budget. In the case of total abandonment of the income test, the annual expenditure resulting from the programme would increase by as much as PLN 14 billion per year ${ }^{5}$.

The combination of two functions of the $500+$ benefit: (i) the social function and (ii) the investment function result from the premises of the programme. $500+$ is a social benefit, i.e. a benefit provided to increase the disposable income of households, thereby increasing consumer capacity and the level of social security of families. But according to the intention set out in the explanatory memorandum to the bill (Seym paper No. 216/2016, justification), the $500+$ benefit is also a form of state participation in financing the cost of raising children. In this context children are treated not only as a private good, but also as a public good. In other words, the 500+ benefit is in this sense the state investment expenditure for the creation of the public good, and not a social transfer supporting private household consumption. The indicated second aspect of hybridity is perceived - so far - only in expert circles. In general public perception, $500+$ is a social benefit (CBOS 2017a).

The third aspect of the programme's hybridity concerns including two operational objectives in its structure, i.e.: (i) limiting the poverty of families, absolute poverty in large families with many children (short-term target) in particular, and (ii) increasing family fertility (long-term target). This aspect, like the second aspect, reflects the project proponent's intentions. Hence also in this approach, hybridity is used intentionally. The hybrid nature of PR500+ is illustrated in Table 1.

$5 \quad$ Under the existing rules the PR 500+ benefit benefits $57.2 \%$ of all children under 18 - see MRPiPS Report 2017. 
Table 1. The hybrid nature of the Family 500+ Programme

\begin{tabular}{|c|c|c|}
\hline Aspect of hybridity & Function A & Function B \\
\hline $\begin{array}{c}\text { Combining the principles } \\
\text { of accessibility of benefits: }\end{array}$ & $\begin{array}{c}\text { The principle of universal } \\
\text { support: a benefit dedica- } \\
\text { ted to all families bringing } \\
\text { up children (in the case of } \\
\text { the second and subsequent } \\
\text { children) }\end{array}$ & $\begin{array}{c}\text { The principle of selective } \\
\text { support: benefit addressed } \\
\text { to poorer families (income } \\
\text { test applied to the first child } \\
\text { in the family) }\end{array}$ \\
\hline $\begin{array}{c}\text { Combining the benefits } \\
\text { function }\end{array}$ & $\begin{array}{c}\text { Classic social function: } \\
\text { increasing the disposable } \\
\text { income of families upbrin- } \\
\text { ging children }\end{array}$ & $\begin{array}{c}\text { Investment function: } \\
\text { State participation in the } \\
\text { cost of raising children } \\
\text { - a form of investment in } \\
\text { children as a public good }\end{array}$ \\
\hline $\begin{array}{c}\text { Combining a short-term } \\
\text { and long-term goal }\end{array}$ & $\begin{array}{c}\text { Short-term goal: reduction } \\
\text { of poverty, especially abso- } \\
\text { lute poverty in large families }\end{array}$ & $\begin{array}{c}\text { Long-term goal: increasing } \\
\text { fertility of families as a way } \\
\text { of slowing down the ageing } \\
\text { of society }\end{array}$ \\
\hline
\end{tabular}

Source: author's own analysis.

\section{Shift in the development paradigm: from the neo-liberal approach to social investment based policy}

The approach adopted in the PR500+ is in line with the premises of investmentbased social policy. The inclination of social policy towards social investment means that at least part of the state's social expenditure ceases to be treated as satisfying the society's important consumer needs, bypassing market mechanisms (decomodification), by the use of public funds, and instead it is treated as expenditures that will provide specific, financially measurable benefits to the society in the future (see Morel, Palier, Palme eds. 2012). In the first place, investment in human capital, education of citizens in particular, is considered to be such as investment expenditure (see Becker 1993). PR500+ is an example of investment-based policy which addresses children and fertility.

Before social investment policy was created in developed countries, the decline in fertility was considered an inevitable side effect of modernisation processes and was associated with the individualisation of lifestyles (a growing scepticism toward social roles requiring long term commitment) (Kotowska 2017a), consumerism (perception of having children in terms of costs to bear) (Golinowska 1994: 118-119), mass entry of women into the labour market (redefinition of gender roles in the family and society) (Frątczak 2017), but also with the availability of public 
social protection in old age, which in traditional societies was provided by their own children. In other words, the fall in fertility below the simple replacement of generations was associated with increasing prosperity and welfare state institutions, including the state guaranteeing social security for the general population.

In the context of investment social policy, the method of reversing the unfavourable trend of fertility decline does not lie in the state withdrawing from the social protection it guarantees, but vice versa - its extension - so that the social security system supports and does not weaken the procreative decisions. It is not a policy based on withdrawing the state intervention, nor compensatory policy, based on the state providing a compensation for benefits lost by parents on the labour market (employment breaks or restricted economic activity as a result of giving birth to and bringing up children). It is a policy of incentives to invest - invest in children as human capital.

The orientation of social policy on investment in children through income support for the family, as assumed by PR500+, is in line with Gary Becker's approach, perceiving the family as a production unit, not a consumer unit (see Becker 1991). But at the same time it goes beyond the framework of Becker's economic theory of the family. Parents raising a family are treated as going beyond the area of producing private goods; children within the paradigm of investment based social policy are a common good, the production of which determines the future of society as a community. Thus, it is assumed that the state should cover from public funds part of the costs of the family investment, which is the upbringing of children. When adopting such an optic, you can even treat the $500+$ benefit as a quasi-remuneration for parents for their work at home (raising children), regardless of their professional employment.

The PR500+ reverses the direction of the evolution of the national social security system, which, in Poland after 1989, was determined by the trend to move away from universal redistributive programmes to promote selective support programmes ${ }^{6}$. This trend was a manifestation of the neo-liberal transformation strategy, according to which the modernisation of the country was to be ensured by rooting of market mechanisms in the economy and limitation of state intervention in the free play of market forces (Rymsza 2013: 224-232).

In the neo-liberal concept, social support from public funds can in principle be transferred only to the weakest and the poorest, and the remaining citizens should buy social protection on the market, and thus use individual or group foresight programmes organised in a commercial formula ${ }^{7}$. This is because in liberal macroeconomy, social benefits financed from public funds are considered as consumer spending, burdening the state budget and hampering economic development. The income test as a selection tool for those entitled to social support ensures not only the proper selection of beneficiaries (and therefore the aptness of addressing

6 Cf. the comparison of the universal and selective programmes in: Garfinkel ed. 1992.

7 Cf. the description of the liberal social policy model in: Esping-Andersen 1990. 
benefits), but above all limits the scale of social transfers. Hence the orientation of social policy in the neo-liberal transformation project towards social assistance and selective programmes.

PR500+ changes the perception of pro-family social transfers in Poland. Treating the $500+$ benefit as a social investment does not give grounds for, corresponding to the liberal strategy, differentiation of children to those requiring public support and those not requiring; all children in this perspective are a public good (NRR Opinion 2016). It is the recognition of children as a public good that seems to be the most important change at the normative level, where the concept of social investment, of which in Poland PR500+ is a part, contributes to social policy.

\section{Subjectifying treatment of families as a manifestation of the empowerment approach}

PR500+ is an example of the empowerment approach in social policy, consisting of simultaneous strengthening and empowering of recipients of support (understanding of empowerment after Berger, Neuhaus 1997). Thanks to the programme, the level of securing the needs of the family and its members increases (the strengthening function), but it is the parents who decide how they spend the funds received from the state (the empowering function). Therefore, the family is not only the addressee of the state's activities, which is the essence of the objectifying approach in social policy, but is also treated as a co-producer of the public good (raising children), entitled to make decisions as to how to conduct the investment. This in turn is a manifestation of the subjectifying approach. This is an important innovation in planning public action: the empowerment approach is associated with the orientation on social investments, including the co-production of public goods by citizens and the state.

This creates a new area for empirical research: monitoring the spending of funds from the PR500+ and related changes in consumption patterns and managing household budgets. Public statistics tries to face this challenge ${ }^{8}$. This is not an easy task; you have to specify which expenses should be included in the category of investments in children with a deferred social rate of return, and which should be treated as manifestations of the growing current consumption of households.

Some critics of PR500+ emphasise that a better form of family support would be benefits in kind and postulates the use of funds for the construction of nurseries, kindergartens and other instruments from the work-family balance palette

8 This task is undertaken as part of a panel survey on household budgets kept by the Central Statistical Office. 
(Więź 2017, statements by Iga Magda). Supporters of the state's extension of social services infrastructure usually formulate expresis verbis or adopt a hidden assumption that parents are not the best holders of public funds. The conviction that it is experts or public decision-makers who know better how to use these funds effectively is a manifestation of the objectifying approach in the planning of social policy related to family. However this reveals the debate present in the literature on the subject over the years, over how to best solve the problem of poverty: whether a more effective and efficient form of supporting persons and families affected by this problem is financial aid or support in-kind (see Golinowska 1994, chapters 9-10).

Findings on the nature of the phenomenon referred to in the social sciences as "inheritance of poverty" represent the key problem in the dispute over effective combating poverty. Two different descriptions of mechanisms of perpetuating poverty function in the literature on the subject ${ }^{9}$. According to the first, the essence of the socio-cultural inheritance of poverty is the long-term shortage on the side of household income, forcing families to save excessively, which translates into children learning to live in a state of permanent deprivation of needs. The second approach assumes that the cause of poverty lies in dysfunctions in the sphere of spending household resources and is associated with established habits of irrational consumption or life without planning the future. In this approach, persistence of poverty results from faulty socialisation and dysfunction of parents' behaviour, which are passed on to future generations living in the enclaves of poverty.

One can say that we have two different interpretations of the phenomenon of cultural inheritance of poverty. According to the first, the inheritance of poverty is an unwanted result of rational adaptation of individuals and families to a structurally flawed situation related to the social division of labour, i.e. the inability of the parents to earn enough, despite their economic activity (low wage market in certain occupations) or readiness to take up employment (structural unemployment). According to the second interpretation, the inheritance of poverty results from faulty socialisation, which is manifested in fixed tendencies to irrational behaviour in normal life situations.

It is impossible to decide which interpretation is right, as in the enclaves of poverty, the two cultures of poverty meet and mutually penetrate each other (see Bunio-Mroczek 2016). However, it can be assumed that if we are dealing with the dominance of the first type of poverty culture, effective solution of the problem of poverty inheritance should consist of providing families with stable income, as predicted by PR500+. If the second type of poverty dominates, then in order to break the process of inheriting poverty, social work is necessary with the parents' generation to change their attitudes as well as investment in children's education

9 Description of two interpretations of the culture of poverty - see Karwacki, Kaźmierczak, Rymsza 2014, chapter 2 (by Rymsza). 
to enable them to acquire social competences not available in the process of faulty socialisation at home, which in turn favours their use of state-controlled social services infrastructure.

In summary, the PR500+ is an example of a pro-income approach in combating poverty. This is a consequence of the subjective treatment of families, but also results from the assumption that the key cause of the cultural phenomenon of poverty inheritance in the Polish provinces and enclaves of Polish poverty is the low income of families, and not faulty socialisation patterns.

\section{Defects, limitations and possible side effect of the 500+ Family Programme}

The hybridity of the PR500+, consisting of combining different goals, functions and organizational solutions, results in making the programme solutions illegible in its design, which are inconsistently used and remain incompatible with the wider social support system. The following three such drawbacks of PR500+ can be identified: (1) adoption of the rolling definition of the first child in the family; (2) not including the 500+ benefit in family income taken into account when determining the right to other benefits; (3) introducing, through the programme, an additional income criterion, which complicates the social support system.

The adoption of a "rolling" definition of the first child in the family is a way to reduce the scale of social transfers made through the PR500+. According to this definition, the first child in the family is the oldest child, if not older than 18 years of age. The child under PR500+ programme is entitled to support from birth to the age of majority, but when it becomes the oldest in the family within the meaning of the Act (older siblings having exceeded 18 years of age) the right to benefit depends on the family's fulfilment of the income criterion. This solution, structurally somewhat complicated, could be accepted were it not for the failure to include the 500+ benefit, when determining the right to other social benefits, such as family benefits. The rolling definition of the oldest child brings savings to the state budget, which, however, are offset by spending on other social benefits, which would not apply if the $500+$ benefit were included in the family income in the context of an income test.

At the same time, it should be noted that in the context of PR500+ in relation to the first child in the family, the legislator did not use one of the already existing income criteria, but established further one. After the implementation of the PR500+, the Polish social support system contains as many as 6 different income criteria, which makes it structurally complex and highly non-transparent in social perception (NRR Opinion 2016). This system requires ordering. 
As regards negative side effects of the PR500+, the demotivating effect on women in terms of continuing their professional activity during the period of raising children, is of the utmost importance (Magda 2016). According to Iga Magda it was possible to establish a link in the second half of the 2016 between 40-55 thousand women leaving the labour market and the PR $500+$ (IBS Analysis 2016 $)^{10}$. From this perspective, the PR500+ appears as a threat to the preferred, especially in the years after Poland's accession to the EU, concept of work-family balance (see Czepulis-Rutkowska, Mirosław 2017). However, the scale of this side effect is difficult to verify empirically. First of all, the years 2016-2017 were a period of economic prosperity and the lowest level of unemployment in twenty years; the unemployment rate after the introduction of the programme was lower than before its introduction ${ }^{11}$. Secondly, the $500+$ benefit primarily increases the unattractiveness of the lowest-paid jobs and does not necessarily have to limit the employment level of women. It is rather more likely to force a rise in wages. It seems that the relatively small resistance of the employers' organisations to raising the minimum hourly wage, which took place in 2016, can be attributed to the PR500+. It is therefore possible that the PR500+ will serve people in escaping the low wage trap, rather than demotivate them from working. Verification of the impact of PR500+ on the labour market requires further in-depth studies and systematic monitoring.

PR500+ should be "encapsulated" by social services. It is not about limiting the parents' agency in administering the 500+ benefit, but about expanding the field of their choices in the field of investments in education and development of children. Expecting that the availability of an additional benefit will trigger an increased supply of pro-family services, in the context of significant deficiencies in public services infrastructure and highly uneven distribution across the country, translating into territorial differences in quality of life (see GUS 2017b), would be wishful thinking. Similar to the assumption adopted at the threshold of transformation, according to which the free market itself will absorb unemployment resulting from the liquidation of unproductive employment in restructured state-owned enterprises. There is a need to develop a child and family support service system at the local level, taking into account the different needs of families and available to all, without using the income test as a selection tool for those entitled. It means shifting - at least partially - social services from social assistance system, on a similar basis as it was done in the case of a $500+$ benefit. At the moment there is no such integrated social services system $^{12}$.

10 This is several times less than the IBS team expected when preparing the analysis.

11 The unemployment rate in the second quarter of 2016, when the payment of 500+ benefit was started, was according to the BAEL methodology $-3.5 \%$, and in the third quarter of 2017 - 2.7\% (GUS 2017a: 74, table 17).

12 The study work was undertaken in the 2017 at the National Development Council under the President of the Republic of Poland. 


\section{Final conclusions}

Social capacity of the programme. In Poland, PR500+ crosses the Rubicon in terms of programing social policy toward family. The adoption of the Act on State Aid in raising children in 2016 turned out to be so socially successful ${ }^{13}$ that it redefined the area of choice of the public decision maker and thus defined the framework for (further) public activities. After the introduction of the 500+ benefit, the return of the preference for family policy based on indirect solutions appears unlikely, and political parties are likely to compete in the future to fill the gaps in the area of direct state support for families ${ }^{14}$.

Paradoxically, however, it is hybridity that was largely responsible for the resilience of the PR500+. On the one hand, it turned out to be so widespread that it changed the philosophy of organisation of social support: from the scheme based on addressing support only to the poorest people and families, which dominated during the transformation period, towards universal programmes addressed to all citizens. On the other hand, maintaining the element of selectivity limited the criticism of the PR500+ on the part of opinion-forming liberal circles. In this context, the possibility of presenting PR500+ as an element of the logic of modernisation, rather than counter-modernisation: as a form of social investment, and not "handouts for the poor", became an important element in public discourse.

It is worth noting that for similar reasons, the Third Way programme implemented in the United Kingdom by the Labour Party during the leadership of Tony Blair (Blair 1998), was successful. The Third Way was constructed according to the logic of hybridity, based on a conscious combination of opposites, in accordance with the philosophy proposed by Anthony Giddens (Giddens 1998). It seems that in European social policy time has come for the implementation of hybrid solutions and the introduction of multi-sector solutions, in line with the concept of a welfare mix (see Johnson 1999).

Public debate as a clash of interests. The Polish public debate focused on the functioning of the PR500+ is characterised by a tendency to stereotype and stigmatise poorer families. Criticism of the PR500+ beneficiaries concerns to a large extent behaviour that cannot be considered socially dysfunctional. This is not a critique of pathological behaviours such as "they are spending their benefits on alcohol", "they do not want to work", etc. There is a lot of disbelief and indignation that "they went with the children to the seaside", "they bought a second-hand car", "they paid off short-term loans", "they no longer want to work in the supermarket for minimum wages". Yet these and similar decisions are manifestations of rational behaviour, which demonstrate the aspirations of beneficiaries to the lifestyle of the

13 A year after the introduction of PR500+, 77\% of Poles supported it - see CBOS 2017a.

14 The distinction between the implicit and explicit family policy following Kamerman 1995. 
middle classes. They confirm the accuracy of the organisation of the PR500+ as an income support programme ${ }^{15}$. The consumer choices made by the beneficiaries of the programme and the behaviour on the labour market are generally conducive to raising the children's aspirations for social promotion and their fuller participation in social life (Kośny 2017).

What is the meaning of the social popularity of $500+$ and the simultaneous numerous voices critical of the programme and its beneficiaries, which have been expressed by representatives of the elite opinion-makers? The quarter of a century following 1989, including the transformation of the political system crowned with Poland's accession to the EU (1989-2004) and the years of post-accession modernisation of the country (2005-2015) is a period of spectacular economic development of Poland. It is just that the fruits of this development were consumed in a way beneficial for the emerging post-transformation elite, with the marginalisation of interests and aspirations of poorer groups and social strata. In the autumn of 2015, at the polling urns, Poles from smaller towns, or working in the less-paid professions, claimed their rights to participate in the benefits of the country's development. This share of benefits was guaranteed by the social programme of Law and Justice Party and that is why it was met with the support of numerous voters. The pro-modernisation Civic Platform (Platforma Obywatelska) ruling in 2007-2015, however, celebrated the successes of a quarter-century transformation from the position of winners, without seeing the need for a more balanced assessment of the Polish transformation. And that is why it lost in the parliamentary elections.

In conclusion, the PR500+ is a manifestation of the policy of empowering families that have lived so far in the culture of poverty. The vast majority of beneficiaries make rational use of the opportunities created. And this meets with the criticism of the "winners of the transformation". This can be interpreted as a manifestation of the aspiration of these circles to maintain their privileged social position. Thus, the expert and media debate around the PR500+ to a lesser extend serves to diagnose the situation of the beneficiaries of the programme. It rather is a field where the interests of the "winners" of the Polish transformation are articulated.

Towards a social investment policy. PR500+ is an example of investing public funds in human capital. The family ceases to be treated as a consumer unit and begins to be perceived as a production unit. The children are treated as the main public good that families produce. This is in line with the latest trends in the European social policy, where social policy is increasingly referred to as the policy of social investment, and family policy even becomes child-centred (see WarzywodaKruszyńska 2017).

15 This aspect of the PR500+ is highlighted by experts of the Large Family Association 3 Plus (Stowarzyszenie Dużych Rodzin 3 Plus) - cf. Więź 2017, statements by Joanna Krupska. 
Pro-family transfers are not only socially accepted, but in fact there is a functional demand for them. The pro-social orientation of the PR500+ corresponding to the neo-Keynesian logic of stimulating development through public spending has met this demand. Thus, the PR500+ is a harbinger of a fundamental departure from neo-liberal programming of the functioning of the social sphere. This departure is necessary, and even indispensable, if Poland is to develop in a more balanced manner and for the general public to benefit from the benefits of this development. The combination of the social benefits function of PR500+ with the investment function has opened the way to other pro-investment solutions in Poland's social policy. An example of this is the government programme of public investment in cheap housing for rent for young families (with the option of deferred purchase - for those interested), referred to as the Apartment +.

This does not mean, however, that the concept of system transformation based on neo-liberal assumptions was incorrect. Rather, following the change of the political system, the neo-liberal strategy exhausted its potential, and its continued application in the post-accession period in fact strengthened the socalled dependent development. Therefore, a fundamental change in the country's development strategy is needed. This shift was defined in Poland in the formula of responsible development (SOR 2016), one of the dimensions of which is the combination of economic development with social development: one that promotes an inclusive and cohesive society. This is facilitated by PR500+ which is a programme that invests in children as a public good.

Taking into account its hybrid nature, it is possible to build a social and political consensus around PR500+, defining a new framework of pro-family and pro-investment state social policy. The introduction of the $500+$ benefit was preceded by numerous family-oriented changes in social policy, although with a smaller scale and impact. Examples of such solutions included: (i) oneoff benefit following the birth of a child, (ii) the Large Family Card, (iii) extension of parental leave. The strength of PR500+ lies not in the fact that it is a harbinger of a new approach in social policy of the state, but that through its momentum and social validity it is a breakthrough point, deciding for the (possible) sustainability of the earlier turn of policy towards pro-family solutions (Rymsza 2016: 67-72). It is an incontrovertible fact that the PR500+ introduced in Poland an atmosphere of growing polarisation on the political scene, producing a permanent social division (CBOS 2017b). Nevertheless, the author of these words expresses the hope that the above-mentioned objective premises will prove stronger than the conditions of the mentioned division, and it will be possible in the future to build a consensus around the assumptions of the social investment policy. 


\section{References}

Act on State Support in Raising Children (2016), Ustawa z dnia 11 lutego 2016 roku o pomocy państwa w wychowywaniu dzieci, Dz.U. 2016, poz. 195.

Becker G. (1993), Human capital: a theoretical and empirical analysis, with special reference to education, Chicago: The University of Chicago Press

Becker G. (1991), A treatise on the family, Cambridge, MA: Harvard University Press.

Berger P., Neuhaus R. (1997), To empower people: The role of mediating structures in public policy, Washington, D.C: American Enterprise Institute.

"Bilans programu 500+" (2017), Dyskusja redakcyjna [Editorial Discussion], Więź, No. 3.

Blair T. (1998), The third way. New politics for the new century, London: Fabian Society.

Bunio-Mroczek P. (2016), Wczesne rodzicielstwo: zagrożenie czy szansa. Nastoletni rodzicie z łódzkich enklaw biedy, Łódź: Wydawnictwo Uniwersytetu Łódzkiego.

CBOS (2017a), Ocena programu "Rodzina 500 plus" po blisko roku od jego wprowadzenia, Komunikat z badań nr 36/2017, Warszawa: CBOS.

CBOS (2017b), Monolog, dialog czy kłótnia - Polaków rozmowy o polityce, Komunikat z badań nr 153/2017, Warszawa: CBOS.

Czepulis-Rutkowska Z., Mirosław J. (2017), “Kobiety na rynku pracy a rodzina i polityka społeczna”, [in:] Bednarski M., Czepulis-Rutkowska Z., Głogosz D. (eds.), O racjonalną politykę rodzinną. Rodzina formacja niezastapioną?, Warszawa: Instytut Pracy i Spraw Socjalnych.

Esping-Andersen G. (1990), Three worlds of welfare capitalism, Cambridge: Cambridge University Press.

Frątczak E. (2017), “Rodzina: refleksje nad zmianą i jej kontekstem teoretycznym”, [in:] Bednarski M., Czepulis-Rutkowska Z., Głogosz D. (eds.), O racjonalna politykę rodzinną. Rodzina formacja niezastapiona?, Warszawa: Instytut Pracy i Spraw Socjalnych.

Garfinkel I. (ed.) (1982), Income-tested transfer programs. The case for and against, New York: Academic Press.

Giddens A. (1998), The third way. The renewal of social democracy, Cambridge: Polity Press.

Golinowska S. (1994), Polityka społeczna w gospodarce rynkowej, Warszawa: PWN.

GUS (2017a), Biuletyn Statystyczny GUS, No. 11, Warszawa: Główny Urząd Statystyczny.

GUS (2017b), Terytorialne zróżnicowanie jakości życia w Polsce w 2015 r., Warszawa: Główny Urząd Statystyczny.

IBS Analysis (2016), "Rodzina 500+” a sytuacja kobiet na rynku pracy, available at: http://ibs.org.pl/ events/rodzina-500-a-sytuacja-kobiet-na-rynku-pracy (last accessed 04.05.2018).

Johnson N. (1999), Mixed economies of welfare. A comparative perspective, London: Prentice Hall Europe.

Kamerman S.B. (1995), "Families overview”, [in:] Encyclopedia of Social Work (19 ${ }^{\text {th }}$ ed.), Washington, D.C.: NASW.

Karwacki A., Kaźmierczak T., Rymsza M. (2014), Reintegracja. Aktywna polityka społeczna w praktyce, Warszawa: Instytut Spraw Publicznych.

Kośny M. (2017), Wpływ programu Rodzina 500+ na wzory konsumpcji, prezentacja przedstawiona na seminarium Narodowej Rady Rozwoju [presentation shown during the National Development Council seminar], 13.11.2017, Warszawa, Kancelaria Prezydenta RP. 
Kotowska I.E. (2017a), "Polityka rodzinna a nowe koncepcje dotyczące spadku płodności w krajach europejskich”, [in:] Bednarski M., Czepulis-Rutkowska Z., Głogosz D. (eds.), O racjonalna politykę rodzinną. Rodzina formacją niezastapioną?, Warszawa: Instytut Pracy i Spraw Socjalnych.

Kotowska I.E. (2017b), Czy Program Rodzina 500 Plus umożliwi trwałe odwrócenie spadku urodzeń $w$ Polsce?, opracowanie przygotowane dla Narodowej Rady Rozwoju, Kancelaria Prezydenta RP, Warszawa 2017, manuscript.

Magda I. (2016), Program 500 Plus - opinia IBS, 2 March 2016, available in the Internet (http://ibs. org.pl/news/program-rodzina-500-plus-opinia-ibs (last accessed 04.05.2018).

Morel N., Palier B., Palme J. (eds.) (2012), Towards a social investment welfare state. Ideas, policies and challenges, Bristol: The Polity Press.

MRPiPS Report (2017), Rodzina 500+. Stan na 31 lipca 2017 roku, Ministerstwo Rodziny, Pracy i Polityki Społecznej, report available in the Internet (www.mpips.gov.pl (last accessed 04.05.2018).

NRR Opinion (2016), Opinia Sekcji Polityka Społeczna, Rodzina Narodowej Rady Rozwoju przy Prezydencie RP w sprawie projektu Ustawy o pomocy państwa w wychowywaniu dzieci przygotowana $w$ ramach konsultacji społecznych, Warszawa, 22 January 2016, manuscript.

Rymsza M. (2013), Aktywizacja w polityce społecznej. W stronę rekonstrukcji europejskich welfare states?, Warszawa: Wydawnictwo IFiS PAN.

Rymsza M. (2016), “Polityka rodzinna: cele, wartości, rozwiązania - w poszukiwaniu konsensualnego programu”, Studia BAS, No 1.

Rymsza M. (2017), “Zrozumieć ten plus”, Więź, No. 3 (669).

SOR (2016), Strategia na rzecz Odpowiedzialnego Rozwoju, Warszawa: Ministerstwo Rozwoju.

Seym Paper (2016), Projekt ustawy o pomocy państwa w wychowywaniu dzieci, druk sejmowy, No. 216, Warszawa.

Szarfenberg R. (2017), Wpływ świadczenia wychowawczego (500+) na ubóstwo ogółem i ubóstwo dzieci na podstawie mikrosymulacji, tekst przygotowany dla Narodowej Rady Rozwoju, Kancelaria Prezydenta RP, Warszawa, manuscript.

Warzywoda-Kruszyńska W. (2017), “Dzieciocentryczna polityka społeczna w założeniach i praktyce”, [in:] Bednarski M., Czepulis-Rutkowska Z., Głogosz D. (eds.), O racjonalna politykę rodzinną. Rodzina formacją niezastapioną?, Warszawa: Instytut Pracy i Spraw Socjalnych.

Zdrowie, praca, rodzina (2014), Program Prawa i Sprawiedliwości 2014, PiS, Warszawa. 